\title{
ANALYSIS OF WATER MASS VARIATION IN WETLANDS USING DATA FROM GRACE SATELLITE MISSION: THE PANTANAL CASE
}

\author{
Cecilia Cornero ${ }^{1}$, Ayelen Pereira ${ }^{1}$, Ana Cristina Oliveira Cancoro de Matos ${ }^{2}$ and María Cristina Pacino ${ }^{1}$
}

\begin{abstract}
The natural heritage of biodiversity of the Paraguay river basin is subject to potential impacts due to climate change. To monitor these environments at large spatial scales, the satellite gravity mission GRACE (Gravity Recovery and Climate Experiment) provides time-variable Earth's gravity field models that reflect the variations due to mass transport processes, like continental water storage changes. The purpose of this work is to analyze the spatial and temporal water storage changes for period 2003-2014 using the Equivalent Water Height (EWH) derived from the GRACE solutions in the Pantanal region, one of the most biologically rich environments of the planet. The comparison with EWH and river gauge data at different stations distributed over the Pantanal area was carried out. In order to validate the satellite results, the correlation analysis between the water mass changes and river gauge measurements was obtained, and also the phase differences were analyzed. High correlations were detected at the north, and lower ones towards the south of the Pantanal. The EWH were also contrasted with soil moisture and rainfall data models. The results showed a good agreement between the signals for the area under study.
\end{abstract}

Keywords: water storage, satellite gravity mission, river gauge, rainfall.

RESUMO. 0 patrimônio natural de biodiversidade da bacia do rio Paraguai está sujeito a potenciais impactos das mudanças climáticas. Para monitorar esse ambiente em escala espacial, a missão satelital GRACE (Gravity Recovery and Climate Experiment) fornece modelos do campo de gravidade da Terra variáveis no tempo devido ao processo de transporte de massa, como as variações de armazenamento de água continentais. 0 objetivo deste artigo é analisar a variabilidade espacial e temporal de armazenamento de água para o período 2003-2014 através da altura equivalente d'água (EWH) derivada das soluções de GRACE na região do Pantanal, um dos ambientes biologicamente mais ricos do planeta. Comparações dos dados de EWH e alturas d'água in-situ foram feitas para diferentes estações distribuídas na região do Pantanal. Com a finalidade de validar os resultados de satélite, foi feita a análise de correlação entre as mudanças de massa d'água e as medições das réguas linimétricas fixadas nas margens dos rios. As diferenças de fase também foram analisadas. Ao Norte do Pantanal foram detectadas altas correlações entre as duas alturas (EWH versus in-situ), e baixas em direção ao sul. 0 EWH também foi validado com modelos de umidade do solo e precipitação. Os resultados mostraram uma boa concordância entre os sinais para a área em estudo.

Palavras-chave: armazenamento de água, missão satelital, cotas do nível d'água, precipitação.

\footnotetext{
${ }^{1}$ National University of Rosario - CONICET, Area of Geodynamics and Geophysics, Faculty of Exact Sciences, Engineering and Surveying, Av. Pellegrini, $250,3^{\circ}$ (S2000BTP), Rosario, Santa Fe, Argentina. Phone: +54(341) 4802650, int. 117; Fax: +54(341) 4802654 - Emails: ccornero@fceia.unr.edu.ar; apereira@fceia.unr.edu.ar; mpacino@fceia.unr.edu.ar 2Universidade de São Paulo, Department of Transportation Brazil, Laboratory of Topography and Geodesy, CNGE0, Rua Cotoxó, 611, Conj. 75, Perdizes, 05021-000 São Paulo, SP, Brazil. Phone: +55(11) 3091-5439 - E-mail: acocmatos@gmail.com
} 


\section{INTRODUCTION}

The knowledge of the surface water cycle has several applications, such as monitoring and forecasting flood, sediment flows over basins and geomorphology domains (Alves Costa et al., 2012). In most world river basins, information on the hydrological regime is mainly based on rainfall, water level and discharge data. However, in many parts of the world, substantial sections of river are void of in situ data.

In the recent years, remote sensing data (such as altimetrybased surface water levels and total water storage from space gravimetry) have proved to be very helpful for studying the water balance at sub-basin and basin scales (Xavier et al., 2010).

Most of the temporal gravity changes detected by recent gravity satellite campaigns can be associated with the variations in terrestrial water storage, which includes hydrological reservoirs changes, groundwater, soil moisture, lakes, streams, snow, ice and glaciers (Wahr et al., 2004; Ramillien et al., 2005; Velicogna \& Wahr, 2006; Chen et al., 2006, 2007, 2010; Rodell et al., 2007; Andersen et al., 2008; Klees et al., 2008; Sandberg Sørensen \& Forsberg, 2010; Pereira \& Pacino, 2012; Pereira et al., 2012; Frappart et al., 2014). The total water storage, now measured by the GRACE (Gravity Recovery and Climate Experiment) space gravimetry mission, is a variable which was not accessible from direct observations so far.

The Paraguay river basin is a region of interest because of its high biodiversity value. The Pantanal, located within this basin, is one of the world's largest and most important wetlands because of the wealth of wildlife and the environmental services that provides.

In the Pantanal region more than 4,700 species - including plants and vertebrates - can be found: 3,500 species of that amount are trees and aquatic and terrestrial vegetation; 325 are fishes, 53 are amphibians, 98 are reptiles, 656 are birds and 159 are mammals.

Because of this wetland importance, 3.9 millions of ha of the Pantanal were declared as Protected Area in 1997, and in 2001 it was recognized for the Convention on Wetlands of International Importance - Ramsar. Also, it was declared as National Heritage in Brazil, and the United Nations gave it the title of Humanity Heritage and Biosphere Reservoir in 2000 year (WWF, World Wildlife Fund, 2010).

Temporal and spatial variations of the water storage in the area covered by the basin are difficult to measure using ground data because of the hydrographic system's size; but with the present advance of technologies represented by GRACE data it is possible to detect the monthly spatial changes in the distribution of water masses in these regions. Furthermore, GRACE can map water storage changes to a height of about 1 centimeter for areas ranging in size on the order of $400 \mathrm{~km}$.

The main objective of this work is to map the water storage variability in the Pantanal area using the Equivalent Water Height (EWH) grids from GRACE provided by the Centre National d'Etudes Spatiales/Groupe de Recherche de Géodésie Spatiale (CNES/GRGS). Moreover, the agreement between EWH values with in-situ data from river gauge measurements and with rainfall and soil moisture information is analyzed in order to understand the water cycle in the region.

\section{STUDY AREA}

The Paraguay river basin is located in the central region of South America, and it is one of the main tributaries of the La Plata river hydrographic system. With a total area of approximately $1,095,000 \mathrm{~km}^{2}$, the Paraguay basin occupies part of the territories of Brazil, Paraguay, Bolivia and Argentina.

The Pantanal is one of the largest and best preserved wetlands of the world; with an approximate area of $170,000 \mathrm{~km}^{2}$ and an altitude range between 90 and $200 \mathrm{~m}$, it extends over part of Brazil (70\%), Bolivia (20\%) and Paraguay (10\%). The $60 \%$ of the Pantanal region it is located in the Mato Grosso and Mato Grosso do Sul Brazilian states (Fig. 1). The present investigation focuses on the area corresponding to the Brazilian part of the Pantanal.

The Pantanal boundaries at Figure 1 were made from a shapefile created by Olson et al. (2001), available on <https://www. worldwildlife.org/publications/terrestrial-ecoregions-of-theworld $>$.

The Pantanal system comes from the slight slope of a vast region crossed by the Paraguay river. A variety of lagoons, wetlands and rivers constitutes the floodplain of the upper part of the Paraguay river basin, where the relief is marked by the contrast between the plains - the Pantanal - surrounded by height lands which acts like barriers (the elevations of the plateau).

The system is a sedimentary basin, whose sediments have been accumulated on this crust depression since the Quaternary period. The deep of the sediments varies from $40 \mathrm{~m}$ to $3,000 \mathrm{~m}$.

Regarding the hydrographic characteristics, the Pantanal regime is periodic and seasonal, and several rivers go through this region: Paraguay, Cuiabá, São Lourenço, Piquiri, Taquari, and Negro. This complex hydrographic system, together with the diverse type of soils of the region, generates a variety of landscapes and sub-unities that are subject of different hydrological conditions (Girard et al., 2003). Besides, the Guarani aquifer system has a high influence in the Pantanal due to its proximity.

The delay in the water rise of about 4 months between the northern and southern region of the Pantanal is a consequence of the $0.01 \mathrm{~m} / \mathrm{Km}$ slope in the north-south direction. 


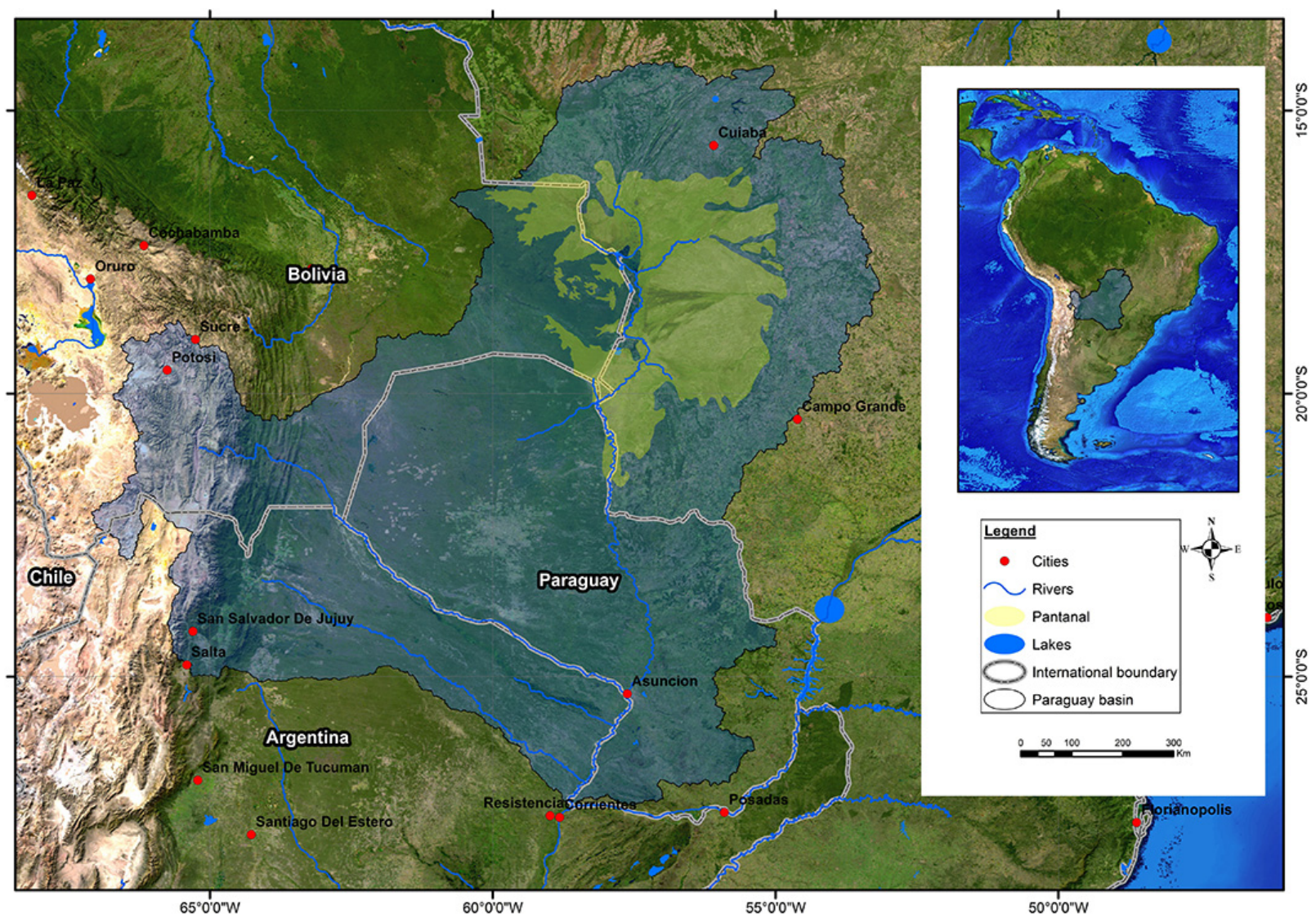

Figure 1 - Paraguay river basin and the Pantanal area.

The Pantanal acts like a regulator for the entire La Plata basin by reducing the water flow of the Paraguay river before its confluence with the Paraná river (Ferrazzoli et al., 2010). If this hydrographic system would not exist, there would be a higher risk of flood of the rivers Paraguay and Paraná, with important consequences for the communities of the countries of Paraguay, Brazil and Argentina.

The total annual precipitations exceed the $1,300 \mathrm{~mm}$; in december takes place the maximum rainfall peak, reaching the $200 \mathrm{~mm}$, and in July and August, the precipitation is minimum and close to zero millimeters (García, 1996). In the rainy season, the water level can raise up to $5 \mathrm{~m}$ more than in the dry season. In this period, the Pantanal is supplied by the groundwater, and that is the reason why in the seasonally flooded or dry plains there are also swamp areas and permanent wetlands.

\section{DATA BASE, METHODOLOGY AND RESULTS GRACE data}

The observed gravity variations are caused by temporal mass changes. These mass variations can be considered as concentrated in a very thin water layer on the surface, with thickness changing in time. In fact, most of the temporal gravity variations are caused by changes in the water storage of the hydrological reservoirs, by the mass movements in the oceans, atmosphere and cryosphere, and by the exchanges between them. The vertical extension of this layer of water is measured in centimeters, which is much smaller than the Earth's ratio or the horizontal variations scales - that are in kilometers - (Wahr et al., 1998).

In this investigation, the EWH Release 03 grids processed by the CNES/GRGS were used (Bruinsma et al., 2010). These grids are given every 30 days for the whole globe, and they were analyzed in the Paraguay river basin and the Pantanal area for the period January 2003-June 2014.

The $1^{\circ} \times 1^{\circ}$ EWH global grids represent the water storage variability and have a spatial resolution better than $450 \mathrm{~km}$, corresponding to spherical harmonic coefficients up to degree 80 .

Ocean tide and barotropic response models, as well as atmospheric pressure dealiasing and Earth tides corrections are applied in the data processing by the CNES/GRGS center. The different models and releases used in this study, together with their references, are detailed in Table 1. 
Table 1 - Models and releases used in this study.

\begin{tabular}{|l|l|l|l|}
\hline & RL03 & Website & References \\
\hline IERS Conventions & 2010 & $\begin{array}{l}\text { https://www.iers.org//ERS/EN/ } \\
\text { Publications/TechnicalNotes/tn36.html }\end{array}$ & IERS (2010) \\
\hline Ocean tide model & FES2012 (LEGOS) & $\begin{array}{l}\text { http://www.legos.obs- } \\
\text { mip.fr/equipes/ecola/projets/fes2012 }\end{array}$ & $\begin{array}{l}\text { Lyard et al., 2006; } \\
\text { Carrère et al., 2012 }\end{array}$ \\
\hline $\begin{array}{l}\text { Atmospheric pressure } \\
\text { dealiasing (processed by } \\
\text { P Gégout, CNRS/GET) }\end{array}$ & $\begin{array}{l}\text { ECMWF } \\
\text { ERA-Interim, } \\
\text { every 3 h }\end{array}$ & $\begin{array}{l}\text { http://www.ecmwf.int/en/research/ } \\
\text { climate-reanalysis/era-interim }\end{array}$ & $\begin{array}{l}\text { Dee et al. 2011; } \\
\text { Berrisford et al., 2011 }\end{array}$ \\
\hline $\begin{array}{l}\text { Ocean barotropic } \\
\text { response model }\end{array}$ & $\begin{array}{l}\text { TUGO (LEGOS), } \\
\text { every 3 h }\end{array}$ & http://grgs.obs-mip.fr/grace/atm_ocean & $\begin{array}{l}\text { Couvelard et al., 2015; } \\
\text { Soufflet et al., 2016 }\end{array}$ \\
\hline
\end{tabular}

The mean gravity field model associated with this version is the EIGEN-GRGS.RLO3.MEAN-FIELD, which is complete to degree and order 260 and it is based on data from LAGEOS (28 years), GRACE (10 years) and GOCE (3 years). According to Alves Costa et al. (2012), the uncertainty of an individual point time series as expressed in EWH is approximately $20 \mathrm{~mm}$.

\section{River gauge measurements}

The river gauge time series were provided by the National Agency of Water of Brazil - Agência Nacional de Águas, ANA - which offers the daily measurements of the water level at each station through the HidroWeb site (http://hidroweb.ana.gov.br). The methodology of acquisition is based on daily in-situ water level data, by visually reading it on a river gauge scale (Vaz de Almeida et al., 2012).

In order to analyze the surface water behavior in the Pantanal, 20 stations well distributed over this region of Brazil were selected (Fig. 2). In Table 2, the characteristics of these stations are presented.

\section{Equivalent Water Height grids}

The EWH grids calculated by the GRGS center are basically obtained following a two-steps method: first a surface loading is determined from a geopotential model; and then, an isotropic expansion filter is used to convert the surface loading in EWH (Vaz de Almeida et al., 2012).

According to Ramillien et al. (2005), the difference between the monthly solutions $G(t)$ from GRACE data for the $t$-epoch and the model $G_{0}$ that represents the static component of the mean gravity field, can be used to obtain the time-variable models $\delta G(t)$.

$$
\delta G(t)=G(t)-G_{0}
$$

By using a long series of GRACE monthly geoids, a temporal mean can be computed, which is further removed to each individ- ual monthly grid. Then, the static geoid contributions related to the Earth's internal structure as well as long-term fluid signals are removed with this procedure. Thus, only the short-term variation associated with the mass redistributions in the surface are shown by the corresponding differences (Ramillien et al., 2005).

The time-variable model $\delta G(t)$ can be expressed as:

$$
\begin{aligned}
\delta G(t)= & \sum_{n=1}^{N} \sum_{m=0}^{n}\left[\delta C_{n m}(t) \cos (m \lambda)\right. \\
& \left.+\delta S_{n m}(t) \sin (m \lambda)\right] P_{n m} \cos (\theta)
\end{aligned}
$$

In Eq. (2), $\delta C_{n} m(t)$ and $\delta S_{n m}(t)$ are the normalized Stokes coefficients - provided by GRGS -; $n$ and $m$ are the degree and order respectively, and $N$ is the maximum degree of the decomposition; $\theta$ is the co-latitude; $\lambda$ is the longitude and $P_{n m}$ are the associated Legendre functions.

The time-variable model $\delta G(t)$ can be assumed as the sum of the $K$-contributions to the surface fluids (regardless of the mass variations induced by the tectonic movements, such as earthquakes and postglacial rebound) and that these $K$ contributions are not inter-related in time and space (Vaz de Almeida, 2009):

$$
\delta G(t)=\sum_{k=1}^{K} \delta G_{k}(t)=A \delta G_{k}
$$

where $A$ is a matrix form by a column of blocks of identity matrices that guarantees no correlation between the different dynamic contributions.

Considering that the surface water, the groundwater and the ice sheet constitute the continental water mass, and also assuming that variations of the thickness of this "water layer" are responsible for the $\delta G(t)$ anomaly, $\delta G(t)$ can then be expressed in terms of $E W H(t)$.

According to Vaz de Almeida et al. (2012), the water mass anomaly coefficients $\delta C_{n m}^{h}(t)$ and $\delta S_{n m}^{h}(t)$ of the $E W H(t)$ 


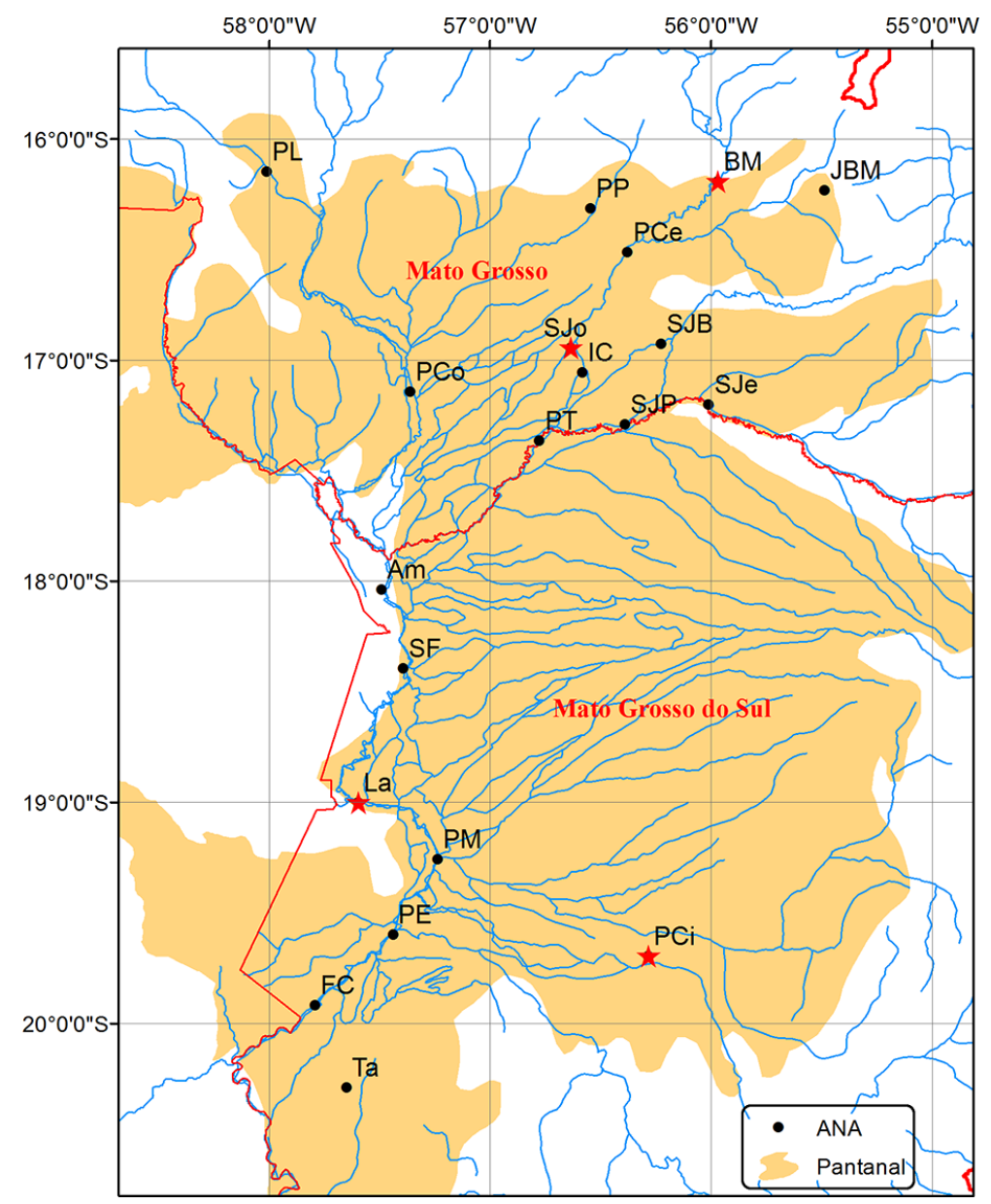

Figure 2 - River gauge stations from ANA in the Pantanal area (the selected ones for further analysis are marked with a star).

harmonic series can be estimated assuming a surface density associated with surface water mass as expressed in Eq. (4), where $W_{n}^{O}$ is an isotropic filter that weights the surface density coefficients:

$$
\left\{\begin{array}{l}
\delta C_{n m}(t) \\
\delta S_{n m}(t)
\end{array}\right\}=W_{n}^{O}\left\{\begin{array}{l}
\delta C_{n m}^{h}(t) \\
\delta S_{n m}^{h}(t)
\end{array}\right\}
$$

Figure 3 shows the annual EWH for the period January 2003June 2014 for the Paraguay river basin. A negative EWH trend can be found at the west of the basin, where the Pantanal is located.

\section{Correlation analysis}

In order to validate the EWH results, these were compared with hydrometric heights series. The in situ river gauge time series of 30 days intervals from ANA were computed in two steps in order to make the data consistent with the EWH grids from GRACE data. First, the missing data series of ANA was completed. In those cases where was any gap in the data, a linear function up to 40 days of gap was applied. For the $H s$ stations under study, this 40 day interval was almost linear. Then, moving averages were performed over 30-day periods for the river gauge series.

The EWH temporal series were interpolated with bilinear interpolation by using the nearest neighbor method in order to obtain the water storage at the same hydrometric $H s$ station.

The determination coefficient $R^{2}$ can be defined as:

$$
R^{2}=\left(\frac{\operatorname{Cov}(E W H(t), H s(t))}{\sigma_{E W H(t)} \cdot \sigma_{H s(t)}}\right)^{2}
$$

In Eq. (5), $R$ is the Pearson coefficient - correlation -; $E W H(t)$ and $H s(t)$ are the EWH from GRACE and the river gauge measurements respectively for the $t$-epoch; and $\sigma_{E W H(t)}$ and $\sigma_{H s(t)}$ correspond to the standard deviations of $E W H(t)$ and $H s(t)$ respectively.

The scale factor of two variables, $X$ and $Y$, can be obtained with the regression line. Assuming a lineal relation between the 
Table 2 - Name of Station, Code, River and State, for the ANA stations in the Pantanal.

\begin{tabular}{|c|c|c|c|c|c|}
\hline Station & Code & River & State & Latitude & Longitude \\
\hline Barão de Melgaço & BM & \multirow{5}{*}{ Cuiabá } & \multirow{8}{*}{ Mato Grosso } & -16.193 & -55.967 \\
\hline Porto Cercado & $\mathrm{PCe}$ & & & -16.512 & -56.376 \\
\hline São João & SJO & & & -16.944 & -56.633 \\
\hline Ilha Camargo & IC & & & -17.056 & -56.581 \\
\hline Pousada Taiamã & PT & & & -17.366 & -56.775 \\
\hline São Jerônimo & SJe & \multirow{2}{*}{ Piquiri } & & -17.202 & -56.009 \\
\hline São José do Piquiri & SJP & & & -17.292 & -56.387 \\
\hline Porto Conceição & $\mathrm{PC} 0$ & \multirow{7}{*}{ Paraguay } & & -17.143 & -57.359 \\
\hline Amolar & $A m$ & & \multirow{6}{*}{ Mato Grosso do Sul } & -18.039 & -57.489 \\
\hline São Francisco & SF & & & -18.394 & -57.391 \\
\hline Ladário (Base Naval) & $\mathrm{La}$ & & & -19.002 & -57.594 \\
\hline Porto da Manga & PM & & & -19.258 & -57.235 \\
\hline Porto Esperança & $\mathrm{PE}$ & & & -19.601 & -57.437 \\
\hline Forte Coimbra & FC & & & -19.919 & -57.789 \\
\hline Porto Limão & $\overline{P L}$ & Jauru & \multirow{4}{*}{ Mato Grosso } & -16.147 & -58.009 \\
\hline Porto de Poconé & $\mathrm{PP}$ & Bento Gomes & & -16.315 & -56.542 \\
\hline J. de Barão de Melgaco & JBM & Lagoa Chacorore & & -16.233 & -55.485 \\
\hline São José do Boriréu & SJB & São Lourenço & & -16.925 & -56.224 \\
\hline Porto Ciriaco & $\mathrm{PCi}$ & Aquidauana & \multirow{2}{*}{ Mato Grosso do Sul } & -19.697 & -56.281 \\
\hline Tarumã & $\mathrm{Ta}$ & Nabileque & & -20.291 & -57.648 \\
\hline
\end{tabular}

variables $E W H$ and $H s$, the regression line can be defined as follows:

$$
H s(t)=\alpha \cdot E W H(t)+b
$$

where $E W H(t)$ and $H s(t)$ are the values for the $t$-epoch; $a$ (dimensionless) is the line slope; $b$ is the ordinate at the $Y$ axis intersection - the $H s$ value when $E W H$ is zero -. The a coefficient represents the relation between the surface water and the accumulated surface water and groundwater. The theoretical limit of $a$ is 1 , which can occur in the ocean (Matos et al., 2012).

The EWH data and the hydrometric heights represent different magnitudes. While GRACE provides an estimate of the total water storage as a vertical column composed of surface water, groundwater and soil moisture integrated over a time period (monthly or every 10 days), the hydrometric height represents the water level reached in a section of a river that can be measured on a daily basis. Therefore, the correlation analysis refers only to the signals behavior of both series.

Figure 4 shows a bar chart with the $R^{2}$ values, sorted from headwaters to downstream (north-south direction).

According to the results, high correlations (between 0.74 and 0.88) were found in the north of the Pantanal - in the State of Mato Grosso -, and the lowest ones (between 0.23 and 0.68) took place at the south, in the State of Mato Grosso do Sul (see Fig. 2).

The correlation and determination coefficients of the $E W H$ and $H s$ signals are well adjusted over the stations that are closer to the headwaters of the Paraguay river basin; but not so over the same river downstream, where these coefficients are considerably decreased.

Figure 5 shows the time series for the period 2003-2014 for four river gauge measurement stations over the Pantanal region (2 located in the Mato Grosso do Sul state, and 2 in the Mato Grosso). The water level from ANA and the EWH from GRACE are represented by red and blue lines, respectively, together with the determination coefficient and regression line for each one. In the figure, it can be detected a higher phase shift between the signals at the stations in the south of the area under study.

The Brazilian Pantanal region belongs to the Cenozoic hydrogeological domain. This domain consists on formations of different type and thickness of sedimentary rocks, which covers the oldest ones. These have behavior similar to a porous aquifer, and present a primary porosity and a high permeability in sandy soils, see Figure 6(a). In Figure 6(b), the different types of soils of this region are shown. 


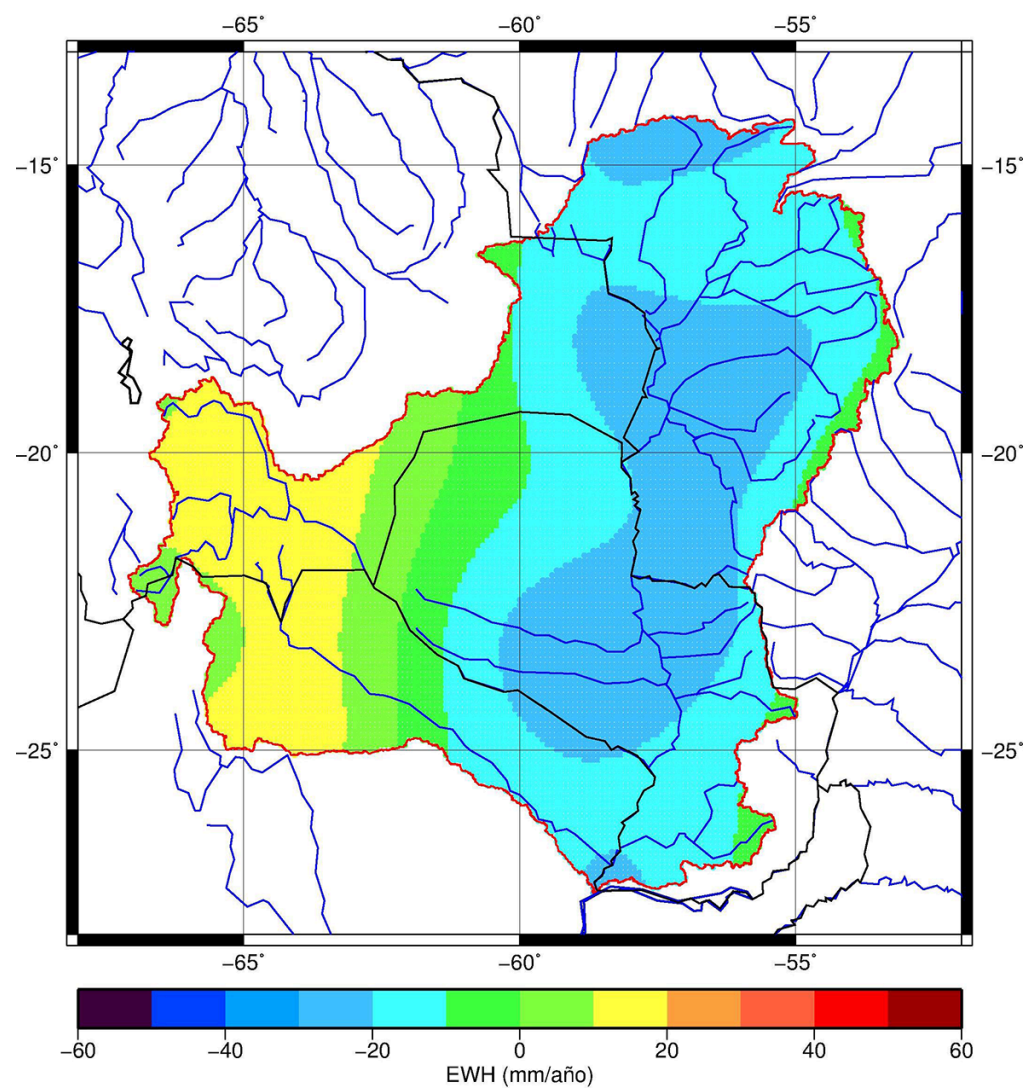

Figure 3 - Mean annual EWH [mm] in the Paraguay river basin from GRGS solutions, for the period January 2003-June 2014.

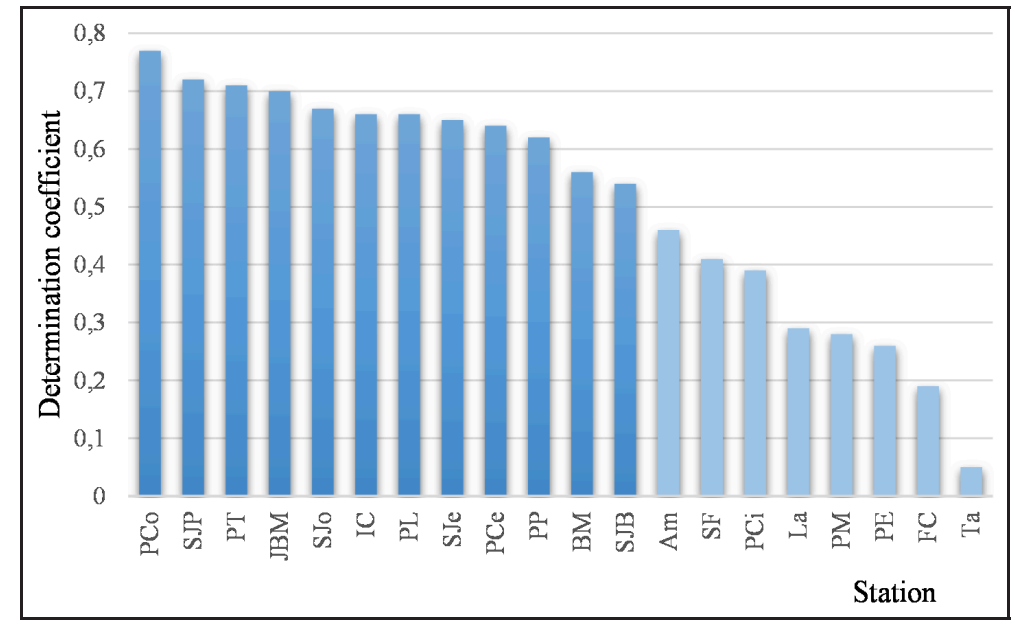

Figure 4 - Determination coefficients for the Pantanal stations, in dark blue the ones corresponding to the state of Mato Grosso (headwaters) and in light blue, the Mato Grosso do Sul stations (downstream).

The hydrological behavior for both states is quite different. In the Mato Grosso the slopes are more important, while in the south there is a lagoon and lake formation trend that delays the surface runoff. This can be the cause for the higher phase shift between the EWH and river gauge measurements in the Mato Grosso do Sul, with the consequent low correlation values.

In the next section, this is analyzed in terms of amplitude and phase for both EWH and hydrometric height signals. 

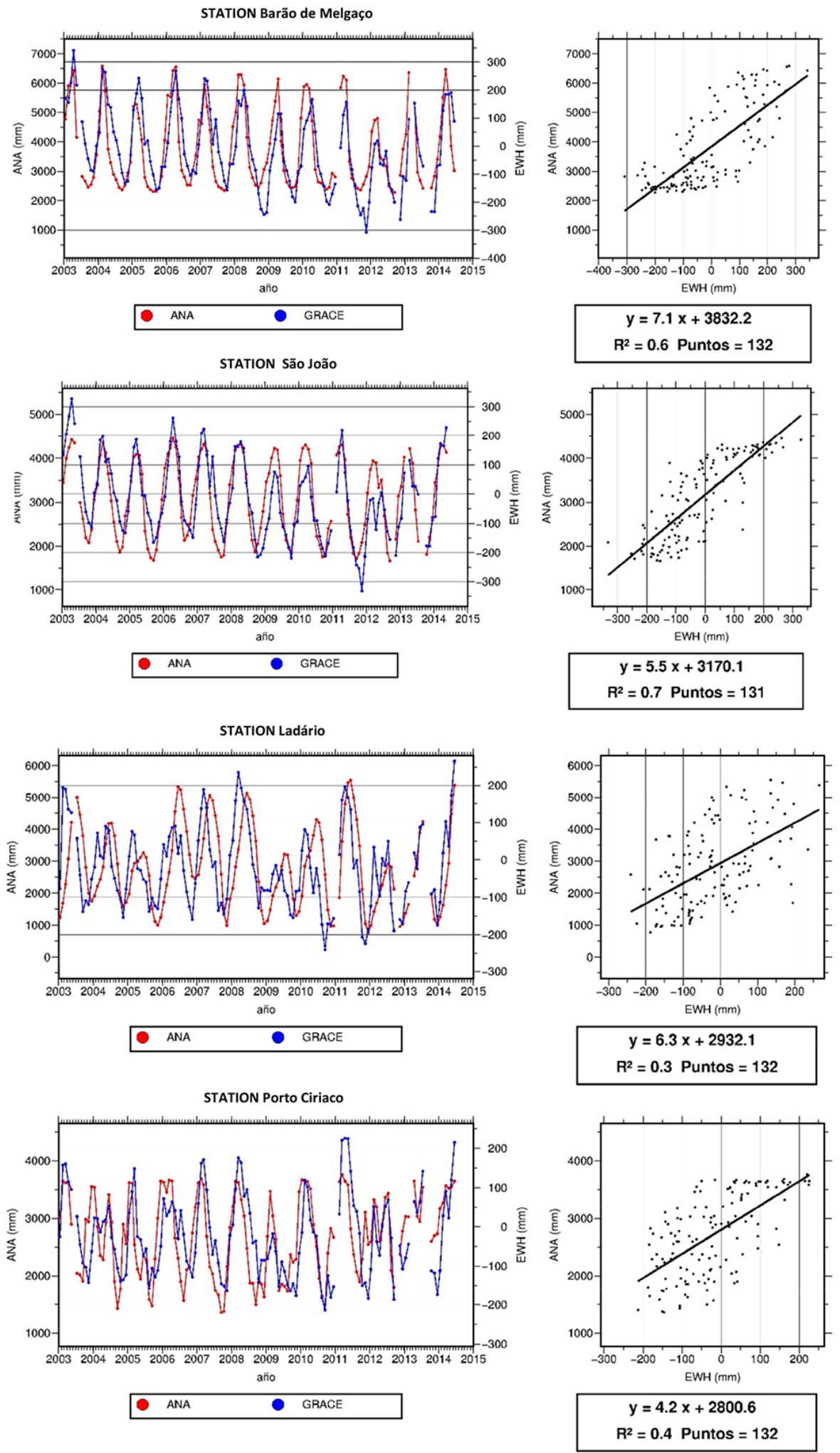

Figure 5 - Time series, determination coefficient and adjustment line for four river gauge stations selected in the Pantanal area, period January 2003 -June 2014 (red lines correspond to ANA and blue ones to EWH from GRACE). The first two stations are located in the state of Mato Grosso, and the others in the Mato Grosso do Sul. 


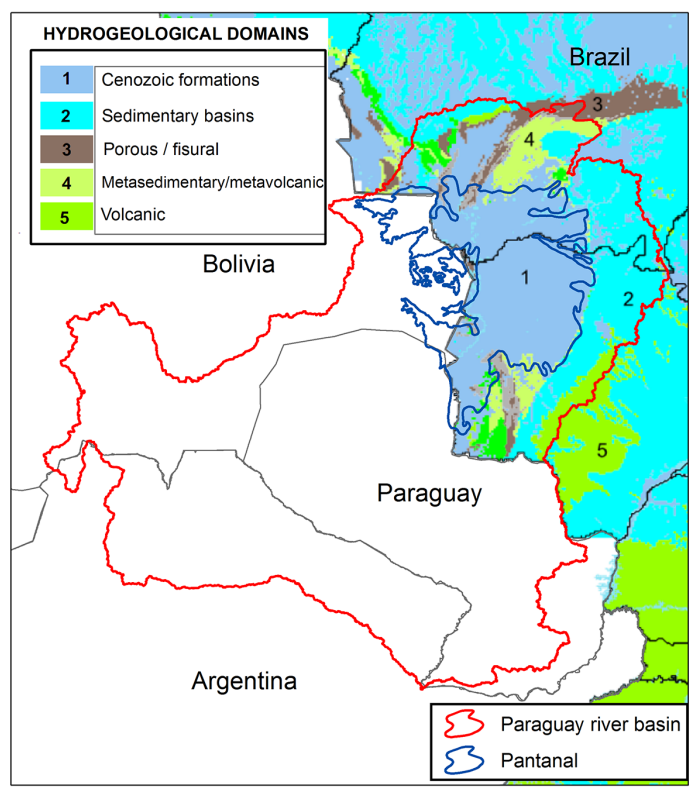

(a)

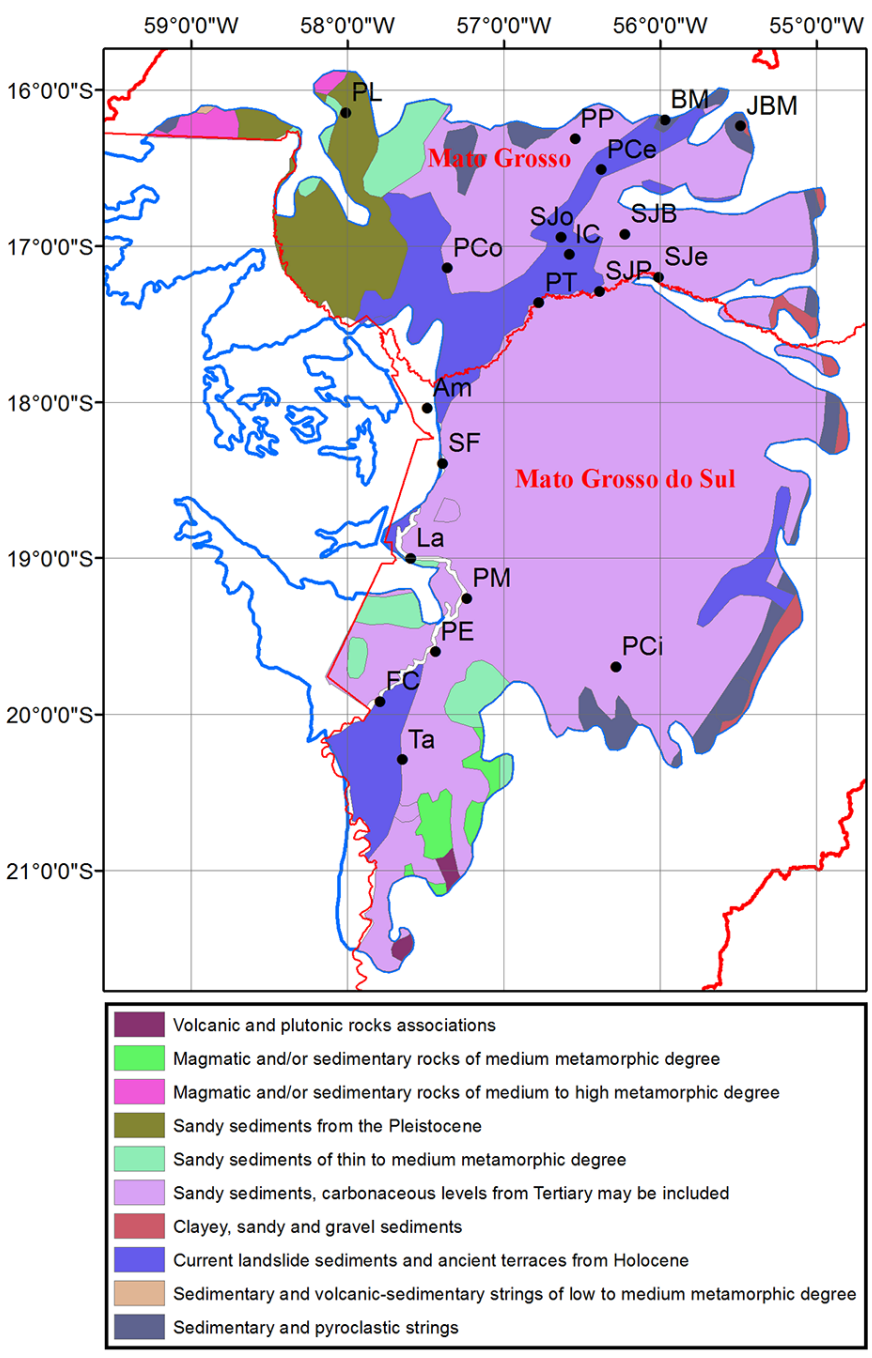

(b)

Figure 6 - (a) Hydrogeological domains (source: http://www.cprm.gov.br/publique/Hidrologia/Mapas-e-Publicacoes/Mapa-Hidrogeologico-do-Brasil-ao-Milionesimo-756.html) and (b) Soils types of the Pantanal.

\section{Phase and amplitude analysis}

Amplitude and phase estimations were computed by an harmonic analysis and a least squares method for $H s$ and $E W H$, respectively (Chatfield, 1996). The phase differences were calculated as Phase $(H s)$ - Phase $(E W H)$.

In Figure 7 , the annual phase differences in days are shown for each Pantanal station.

It was detected that for the stations located in the northern region of the Pantanal (Mato Grosso state), the phase difference was between 0 and \pm 49 days; that is the series can be completely on phase or they can present a phase shift of a month and a half maximum.

On the other side, the southern stations showed higher differ- ences with values ranging between 59 and 159 days. This is indicating a phase shift of the signals of 2-5 months approximately and that in general, GRACE is detecting the water storage changes before the in situ measurements of the hydrometric level.

As it was stated in the previous section, these results can be due to different physical features that domain the region, geological structure, climatic conditions and the influence of nearby basins.

Therefore, the phase differences between the EWH and hydrometric height signals can be attributed to the predominant hydrological processes that show an increasing delay from upstream to downstream of the Paraguay river basin (Matos et al., 2009). 


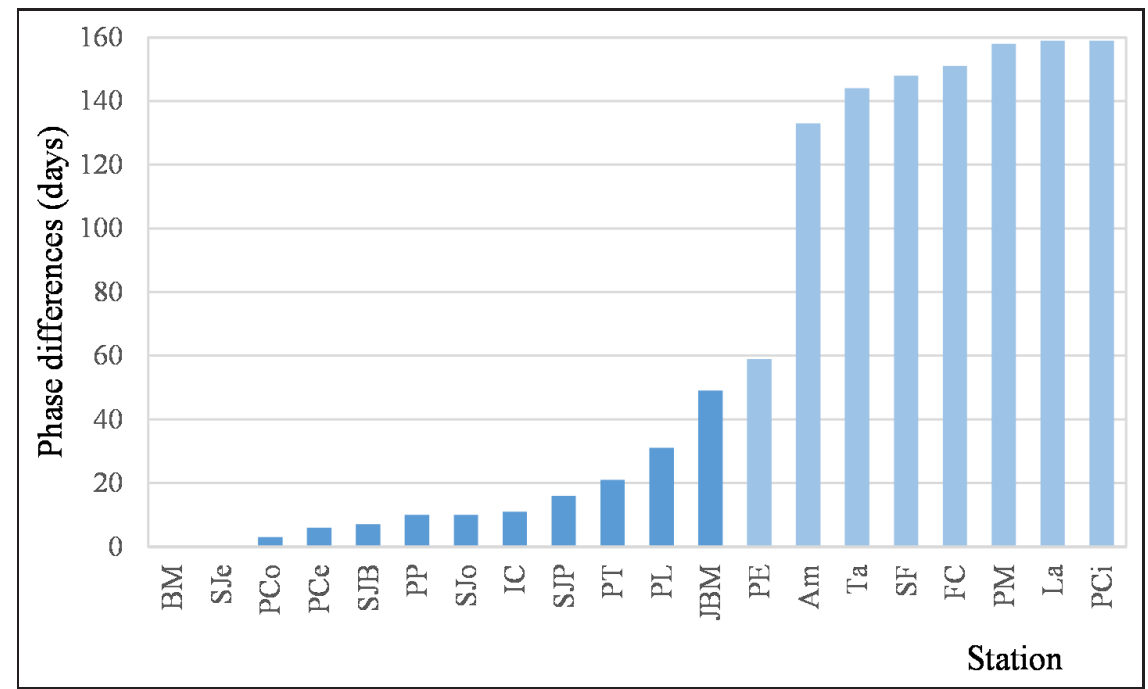

Figure 7 - Annual phase differences in days for the Pantanal stations, in dark blue the ones corresponding to the state of Mato Grosso (headwaters) and in light blue, the Mato Grosso do Sul stations (downstream).

\section{EWH validation with rainfall and soil moisture data}

In order to validate the EWH results for the Pantanal region, a comparison with rainfall and soil moisture data models for the period January 2003-June 2014 was accomplished.

As it was stated in Section 4.2, it is worth to note that the performed analysis is just qualitative, since that GRACE detects the water mass variations as a changing vertical column of continental water (surface water + groundwater + soil moisture) integrated over a time period - EWH -, while the rainfall and soil moisture are just a part of the hydrological cycle.

First, the Global Precipitation model v2.2 data set from GPCP (Global Precipitation Climatology Project, 2015) was used, which consists on monthly $2.5^{\circ} \times 2.5^{\circ}$ precipitation grids. These are produced by the Giovanni online data system (developed and maintained by the NASA Goddard Earth Sciences Data and Information Services Center - GES DISC) and were obtained from the website http://gdata1.sci.gsfc.nasa.gov/daacbin/G3/gui.cgi?instance_id=GPCP_Monthly.

One of the main objectives of the GPCP is to offer data for the analysis of spatial and temporal global precipitation patterns. The monthly precipitation is obtained from a combination of information from rainfall gauge stations, low-orbit infrared geostationary satellites and passive microwaves (Acker \& Leptoukh, 2007).

The accumulated precipitation grids were evaluated over the Pantanal area $\left(58^{\circ} \mathrm{W}-55^{\circ} \mathrm{W}\right.$ longitude, $20^{\circ} \mathrm{S}-16^{\circ} \mathrm{S}$ latitude) for the period 2003-2014, and the comparison with the EWH is shown in Figure 8.

According to the Figure, important EWH peaks can be gener- ally observed in the months of March and April, and lower values took place at September and October. However, maximum accumulated precipitation values generally occurred from December to January, and minimum rainfall values can be found every year between June and August approximately.

Following Frappart et al. (2013), the $R^{2}$ coefficient between EWH and GPCP rainfall was obtained from the original series for the Pantanal region considering the 1 to 4 months phase shifts.

In Figure 9 the scatter plot and $R^{2}$ coefficient for each case is shown.

The coefficient for the original series was very low (less than $0.10)$, but after the 3 months phase shift adjustment, both signals seem to fit very well $\left(R^{2}=0.67\right)$. From the EWH results, it could be stated that GRACE detected the rainfall accumulation in the region with a 3 months delay.

Afterwards, soil moisture data series from GLDAS (Global Land Data Assimilation System, 2015) was used to perform the validation with the EWH results (http://gdata1.sci.gsfc.nasa.gov/ daac-bin/G3/gui.cgi?instance_id=GLDAS10_M). The $1^{\circ} \times 1^{\circ}$ degree GLDAS_NOAH10_M.001 monthly model, average layer 3 $(40-100 \mathrm{~cm})$ was evaluated in the Pantanal region $\left(58^{\circ} \mathrm{W}-55^{\circ} \mathrm{W}\right.$ longitude, $20^{\circ} \mathrm{S}-16^{\circ} \mathrm{S}$ latitude) for the period 2003-2014.

The comparison with the EWH results is presented in Figure 9, where a good agreement in the seasonal cycle of both signals can be detected. According to the Figure, GRACE is detecting the water mass change between 15 days and 2 months after the GLDAS model does; the different type of soils present in the region may be the cause of the mentioned phase shift. 


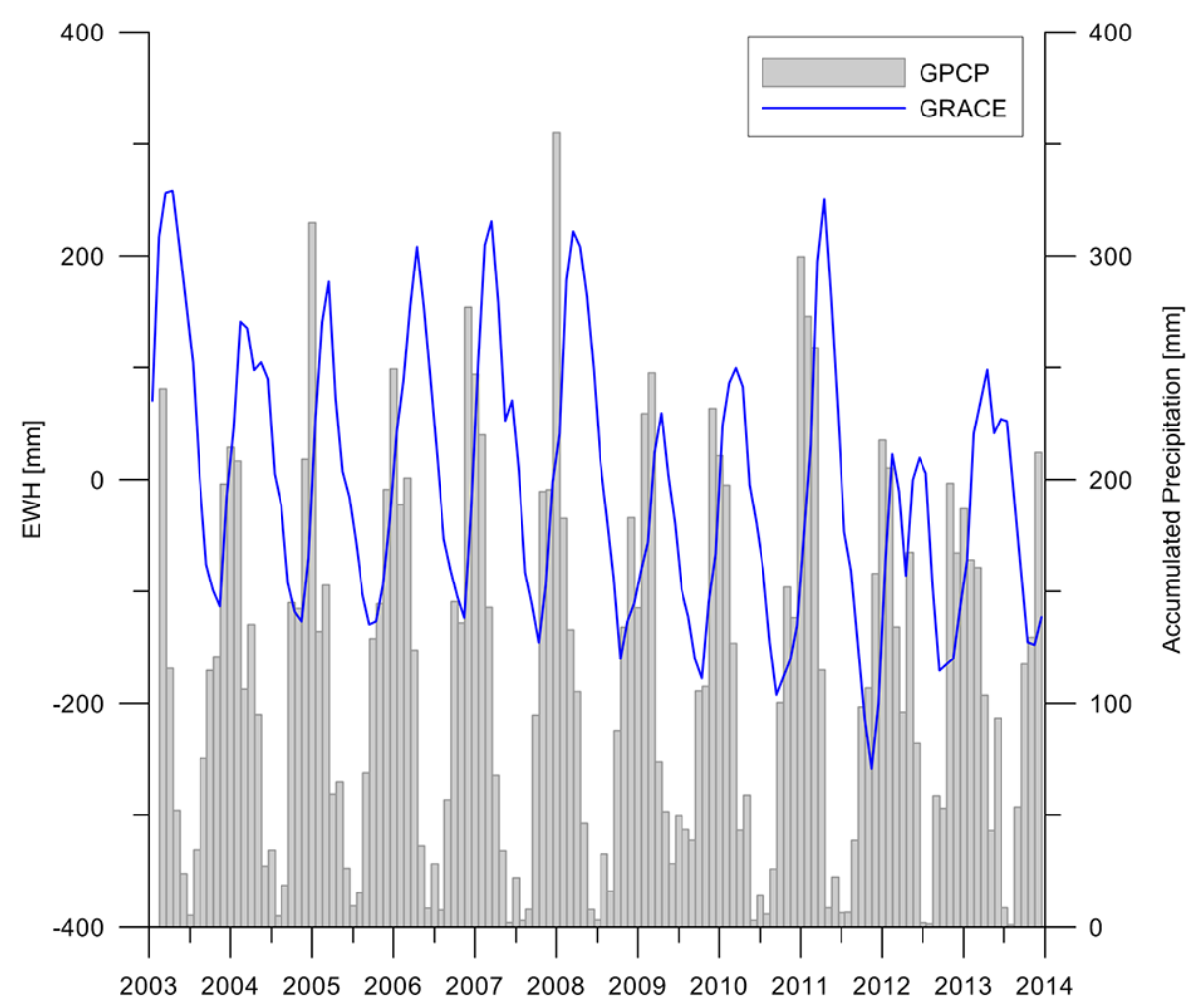

Figure 8 - Equivalent Water Height [mm] from GRACE and accumulated monthly precipitation [mm] from GPCP in the Pantanal area (Region 58W-55W, 16S-20S) for period 2003-2014.

Analyzing Figures 8 and 10, in general EWH from GRACE seems to fit very well with the precipitation and soil moisture variables, but a higher delay of the EWH signal with respect to the first one was detected.

\section{CONCLUSIONS}

According to the obtained results, it can be concluded that GRACE mission could detect the significant mass changes in the Pantanal area.

The EWH annual variation for the Paraguay river basin for the period 2003-2014 (presented in Fig. 3) showed two distinct zones; a negative trend in the western area and a positive one eastwards.

The comparison of EWH derived by GRACE - representing the water ground storage - with in-situ hydrometric heights from river gauge measurements stations from ANA in the Pantanal region has shown a good agreement between both times series. GRACE could detect the seasonal variations, which are related to water level surface and groundwater variations. The $70 \%$ of the correlation results for GRACE and ANA time series was higher than 0.75 . Whereas the resolution of GRACE is greater than $400 \mathrm{~km}$ and the in situ data represents single measurements, it can be concluded that these correlation values are quite high.

In the analysis of the Paraguay river basin wetlands - the Pantanal -, two distinct areas were detected: important correlations were obtained in the north of the Pantanal in the State of Mato Grosso, and lower ones in the south of the region, in the State of Mato Grosso do Sul. The signals that showed higher correlations presented a phase shift of approximately 1 month, and the ones with a lower correlation, more than 2 months.

According to the statistical results, the stations located in the State of Mato Grosso indicate that the applied methodology is representing a good coherency ( $\sim 8 \%$ ) between the space data and the in situ information; whereas for the Mato Grosso do Sul stations, the results were inferior.

The hydrological behavior for both states is quite different. In the Mato Grosso the slopes are more important, while in the south there is a lagoon and lake formation trend that delays the surface runoff. This can be the cause for the higher phase shift between the EWH and river gauge measurements in the Mato Grosso do Sul, with the consequent low correlation values.

A good agreement between EWH and rainfall from GPCP was also observed, but a delay of 3 months in the first variable was found ( $R^{2}$ coefficient was 0.67 ). 


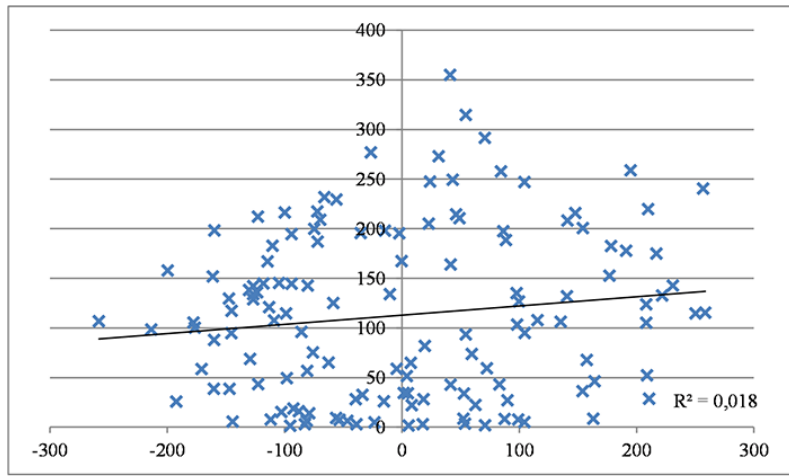

9 (a)- Original Series

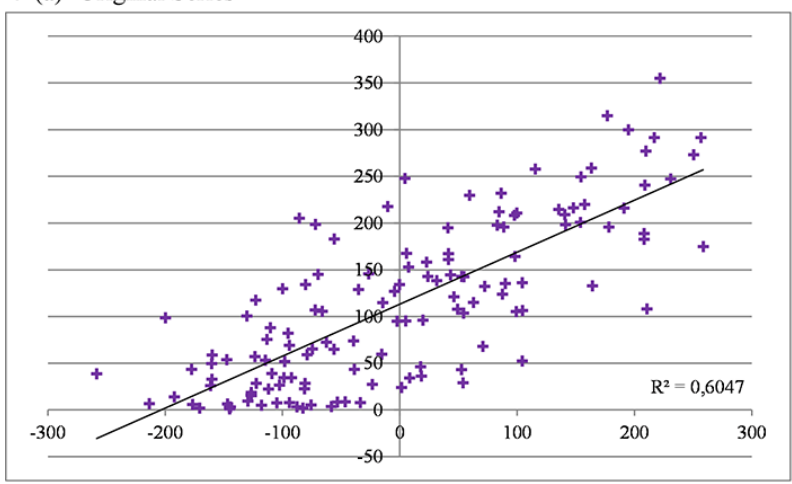

9 (c)- Two months phase shift

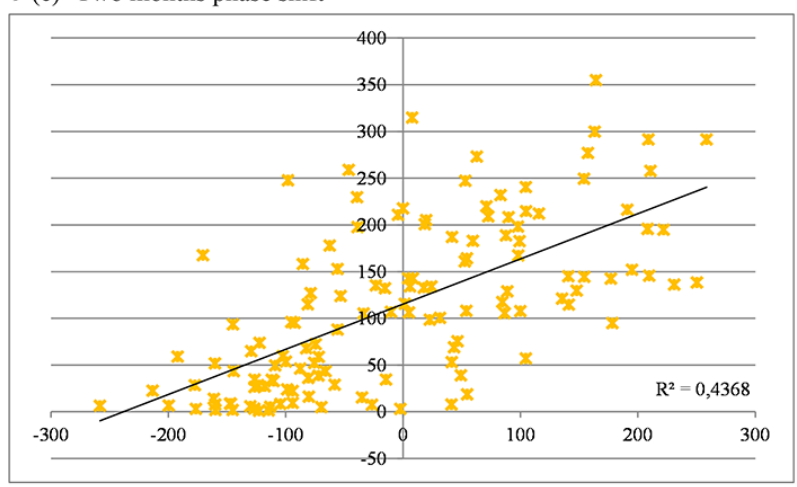

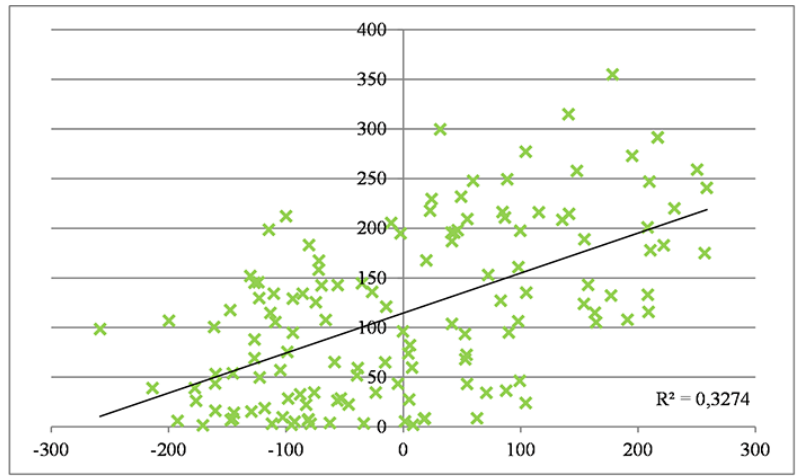

9 (b)- One month phase shift

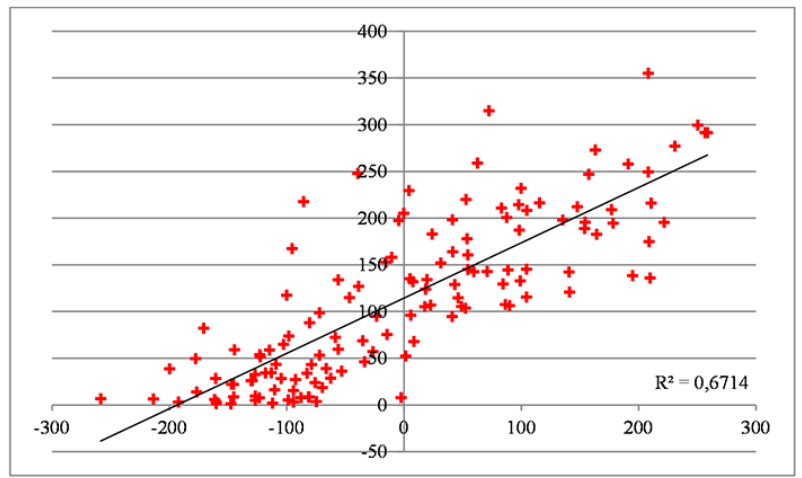

9 (d)- Three months phase shift

9 (e)- Four months phase shift

Figure 9 - GPCP rainfall and GRACE-based equivalent water data and scatter plots, for the original series (a) and the ones for 1 to 4 months phase shifts (b to e).

A better adjustment of the EWH results was found for the soil moisture signal from GLDAS - particularly in the seasonal behavior -; a phase shift was also detected but in this case resulting in a lower time period (15 days to 2 months).

GRACE and ANA data series do not represent the same entity. GRACE provides the behavior of surface water and groundwater flow, while ANA provides only the first. An interesting result would be obtained by reconstructing the GRACE series from the regression line coefficients, then applying ANA data, and thus producing series of surface water on the GRACE data scale. By subtracting GRACE reconstructed series from the original series of GRACE, it can be obtained an estimate of the temporal variation of the groundwater. This analysis will be subject of further investigation.

\section{ACKNOWLEDGEMENTS}

This paper was partially support by CONICET and PICT 20151180 (ANPCyT).

\section{REFERENCES}

ACKER JG \& LEPTOUKH G. 2007. Online Analysis Enhances Use of NASA Earth Science Data. Eos. Trans. AGU, 88(2): 14-17. 


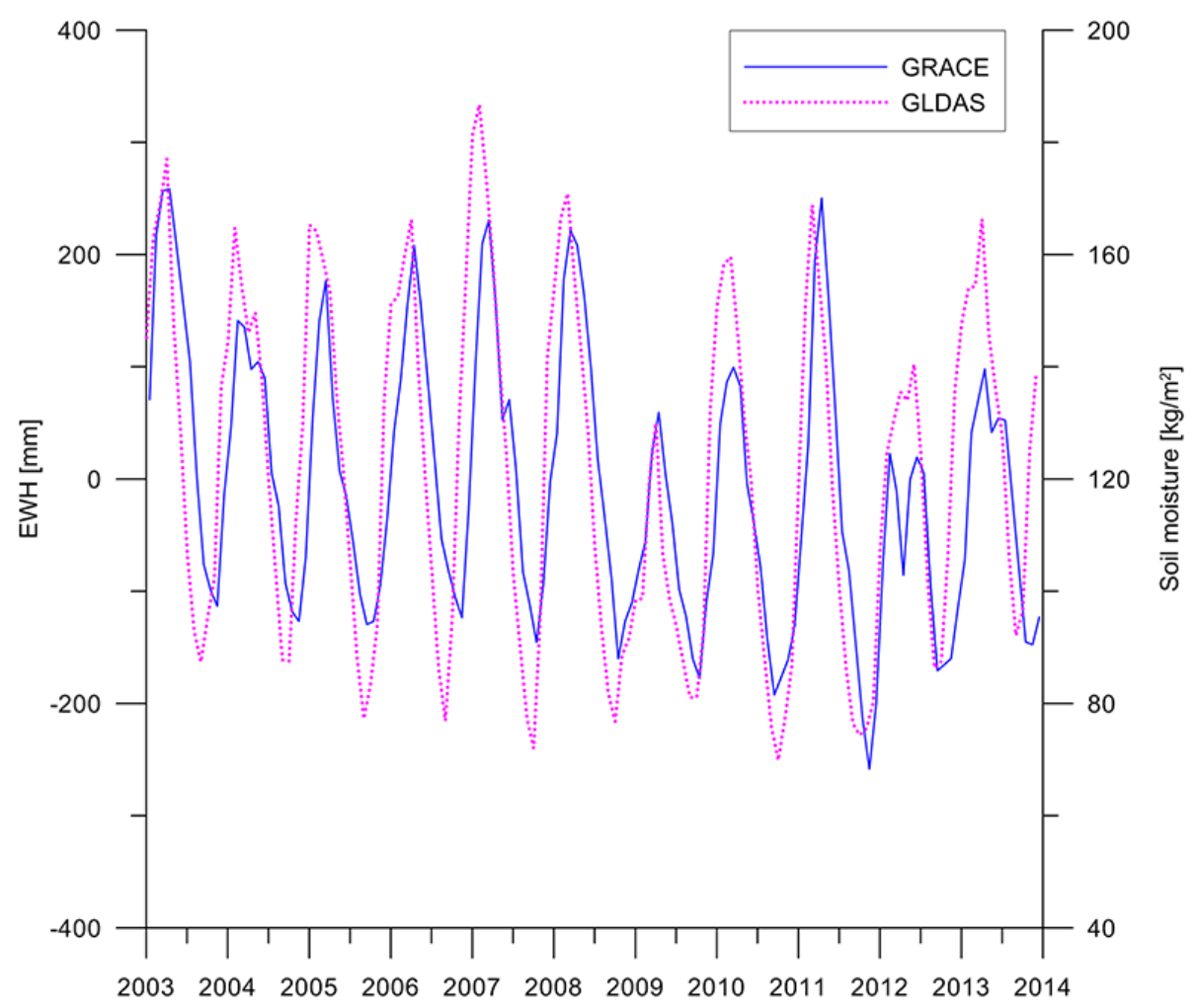

Figure 10 - Equivalent Water Height [mm] from GRACE and soil moisture $\left[\mathrm{kg} / \mathrm{m}^{2}\right]$ from GLDAS in the Pantanal area (Region 58W-55W, 16S-20S) for period 2003-2014.

ALVES COSTA SM, OLIVEIRA CANCORO DE MATOS AC \& BLITZKOW D. 2012. Validation of the land water storage from Gravity Recovery and Climate Experiment (GRACE) with gauge data in the Amazon basin. Bol. Ciênc. Geod., 18(2): 262-281.

ANA - Agência Nacional de Águas. 2011. Paraguay basin information. National Agency of Water of Brazil. Available on:

$<$ http://www.ana.gov.br>. Access on: January 12, 2015.

ANDERSEN 0, BERRY P, FREEMAN J, LEMOINE FG, LUTSCKHE S, JAKOBSENF \& BUTTS M. 2008. Satellite altimetry and GRACE gravimetry for studies of the annual water storage variations in Bangladesh. Terr. Atmos. Ocean. Sci., 19(1-2): 47-52.

BERRISFORD P, DEE DP, POLI P, BRUGGE R, FIELDING K, FUENTES M, KÅLLBERG PW, KOBAYASHI S, UPPALA $S$ \& SIMMONS A. 2011. The ERA-Interim archive Version 2.0. ERA Report Series 1, http://www.ecmwf.int/en/elibrary/8174-era-interim-archive-version-20.

BRUINSMA S, LEMOINE JM, BIANCALE R \& VALES N. 2010. CNES/GRGS 10-day gravity field models (release 2) and their evaluation. Adv. Space Res., 45(4): 587-601. doi: 10.1016/j.asr.2009.10.012.

CARRERE L, LYARD F, CANCET M, GUILLOT A \& ROBLOU L. 2012. FES2012: A new global tidal model taking taking advantage of nearly
20 years of altimetry. Proceedings of "20 Years of Altimetry" meeting, Venice.

CHATFIELD C. 1996. The Analysis of Time Series: An Introduction. Chapman and Hall/CRC, 5th ed., NY, 283 pp.

CHEN JL, WILSON CR, FAMIGLIETTI JS \& RODELL M. 2006. Attenuation effect on seasonal basin-scale water storage changes from GRACE time-variable gravity. J. Geodesy. doi: 10.1007/s00190-006-0104-2.

CHEN JL, WILSON CR, TAPLEY BD, BLANKENSHIP DD \& IVINS ER. 2007. Patagonia Icefield melting observed by GRACE, Geophys. Res. Lett., 34, L22501. doi: 10.1029/2007GL031871.xx

CHEN JL, WILSON CR, TAPLEY BD, LONGUEVERGNE L, YANG ZL \& SCANLON BR. 2010. Recent La Plata basin drought conditions observed by satellite gravimetry, J. Geophys. Res., 115, D22108. doi: 10.1029/2010JD014689.

COUVELARD X, DUMAS F, GARNIER V, PONTE AL, TALANDIER C \& TREGUIER AM. 2015. Mixed layer formation and restratification in presence of mesoscale and submesoscale turbulence. Ocean Modelling, 96(2): 243-253. doi: 10.1016/j.ocemod.2015.10.004.

DEE DP, UPPALA SM, SIMMONS AJ, BERRISFORD P, POLI P, KOBAYASHI S, ANDRAE U, BALMASEDA MA, BALSAMO G, BAUER P, 
BECHTOLD P, BELJAARS ACM, VAN DE BERG L, BIDLOT J, BORMANN N, DELSOL C, DRAGANI R, FUENTES M, GEER AJ, HAIMBERGER L, HEALY SB, HERSBACHH, HÓLM EV, ISAKSEN L, KÅLLBERG P, KÖHLER M, MATRICARDI M, MCNALLYAP, MONGE-SANZBM, MORCRETTEJJ, PARK BK, PEUBEY C, DE ROSNAY P, TAVOLATO C, THÉPAUT JN \& VITART F. 2011. The ERA-Interim reanalysis: configuration and performance of the data assimilation system. Q.J.R. Meteorol. Soc., 137: 553597. doi: 10.1002/qj.828.

FERRAZZOLI P, MEMBER S, RAHMOUNE R, MOCCIA F, GRINGS F, SALVIA M, BARBER M, DOUNA V, KARSZENBAUM H, SOLDANO A, GONIADZKI D, PARMUCHI G, MONTENEGRO C, KANDUS P \& BORRO M. 2010. The effect of rain and flooding events on AMSR-E signatures of $L a$ Plata Basin, Argentina. IEEE Journal of Selected Topics in Applied Earth Observations and Remote Sensing, 3(1): 81-90.

FRAPPART F, RAMILLIEN G \& RONCHAIL J. 2013. Changes in terrestrial water storage versus rainfall and discharges in the Amazon basin. International Journal of Climatology, 33(14): 3029-3046. http://doi.org/10.1002/joc.3647.

FRAPPART F, PAPA F, MALBETEAU Y, LEON J, RAMILLIEN G, PRIGENT C, SEOANE L, SEYLER F \& CALMANT S. 2014. Surface Freshwater Storage Variations in the Orinoco Floodplains using MultiSatellite Observations. Remote Sensing, (September 2014), 89-110. http://doi.org/10.3390/rs70100089.

GARCÍA NO. 1996. The spatial variability of runoff and precipitation in the Rio de la Plata basin. Hydrol. Sci. J., 41: 279-300.

GIRARD P, DA SILVA CJ \& ABDO M. 2003. River - Groundwater interactions in the Brazilian Pantanal. The case of the Cuiabá River. Journal of Hydrology, 283(1-4): 57-66. http://doi.org/10.1016/S00221694(03)00235-X.

GLOBAL LAND DATA ASSIMILATION SYSTEM (GLDAS). 2015. Available on: <http://gdata1.sci.gsfc.nasa.gov/daac-bin/G3/gui.cgi? instance $\mathrm{jd} d=\mathrm{GLDAS10} M>$. Access on: June 16, 2015.

GLOBAL PRECIPITATION CLIMATOLOGY PROJECT (GPCP). 2015. Available on: <http://gdata1.sci.gsfc.nasa.gov/daac-bin/G3/gui.cgi? instance $\_d=G P C P$ Monthly $>$. Access on: June 16, 2015.

IERS 2010. IERS Conventions (2010). PETIT G \& LUZUM B (Eds.). IERS Technical Note No. 36. Frankfurt am Main: Verlag des Bundesamts für Kartographie und Geodäsie. International Earth Rotation and Reference Systems Service (IERS). 179 pp., ISBN 3-89888-989-6.

KLEES R, LIU X, WITTWER T, GUNTER BC, REVTOVA EA, TENZER R, DITMAR P, WINSEMIUS HC \& SAVENIJE HHG. 2008. A Comparison of Global and Regional GRACE Models for Land Hydrology. Survey Geophysics 29: 335-359. doi: 10.1007/s10712-008-9049-8.

LYARD F, LEFÈVRE F, LETELLIER T \& FRANCIS 0. 2006. Modelling the global ocean tides: A modern insight from FES2004. Ocean Dynamics, 56: 394-415. doi: 10.1007/s10236-006-0086-х.
MATOS ACOC, BLITZKOW D, ALMEIDA FGV, BARBOSA ACB \& CAMPOS 10. 2009. Water level temporal variation analysis at Brazilian Basins using GRACE. 2009 Scientific Assembly, B. Aires, Argentina. Aug 31-Sept 4, 2009.

MATOS ACOC, BLITZKOW D, ALMEIDA FGV, COSTA SMA, CAMPOS IO \& BARBOSA AC. 2012. Analysis of Water Level Variations in Brazilian Basins using GRACE. Journal of Geodetic Science, 2(2): 76-87. doi: 10.2478/v10156-011-0034-7.

OLSON DM, DINERSTEIN E, WIKRAMANAYAKE ED, BURGESS ND, POWELL GVN, UNDERWOOD EC, D'AMICO JA, ITOUA I, STRAND HE, MORRISON JC, LOUCKS CJ, ALLNUTT TF, RICKETTS TH, KURA Y, LAMOREUXJF, WETTENGEL WW, HEDAO P \& KASSEM KR. 2001. Terrestrial Ecoregions of the World: A New Map of Life on Earth. BioScience, 51: 933-938.

PEREIRA A \& PACINO MC. 2012. Annual and seasonal water storage changes detected from GRACE data in the La Plata basin. Physics of the Earth and Planetary Interiors, 212-213, pp. 88-99. Elsevier B.V.

PEREIRA A, MIRANDA S, PACINO MC \& FORSBERG R. 2012. Water Storage Changes from GRACE Data in the La Plata basin. Geodesy for Planet Earth, International Association of Geodesy Symposia 136. doi 10.1007/978-3-642-20338-1_75, Springer-Verlag Berlin Heidelberg.

RAMILLIEN G, FRAPPART F, CAZENAVE A \& GÜNTNER A. 2005. Time variations of land water storage from an inversion of 2 years of GRACE geoids. Earth and Planetary Science Letters, 235(1-2): 283-301.

RODELL M, CHEN J, KATO H, FAMIGLIETTIJS, NIGRO J \& WILSON CR. 2007. Estimating groundwater storage changes in the Mississippi River basin (USA) using GRACE. Hydrogeology Journal, 15(1): 159-166.

SANDBERG SØRENSEN L \& FORSBERG R. 2010. Greenland Ice Sheet Mass Loss from GRACE Monthly Models. In: Proc. IAG Symposium on Gravity, Geoid and Earth Observation, (135), Part 7, 527-532. doi: 10.1007/978-3-642-10634-7_70, Springer.

SOUFFLET Y, MARCHESIELLO P, LEMARIÉ F, JOUANNO J, CAPET X, DEBREU L \& BENSHILAR. 2016. On effective resolution in ocean models. Ocean Modelling, 98: 36-50. doi: 10.1016/j.ocemod.2015.12.004.

VAZ DE ALMEIDA FG. 2009. Variação temporal do campo gravitacional detectada pelo satélite GRACE: Aplicação na Bacia Amazônica. São Paulo. Doctorade Thesis. EP/USP, São Paulo, SP, Brazil. 147 pp.

VAZ DE ALMEIDA FG, CALMANT S, SEYLER F, RAMILLIEN G, BLITZKOW D, MATOS ACC \& SILVA JS. 2012. Time-variations of equivalent water heights from GRACE Mission and in-situ river stages in the Amazon basin. Acta Amazonica, 42(1): 125-134. doi: 10.1590/S0044-59672012000100015.

VELICOGNA I \& WAHR J. 2006. Acceleration of Greenland ice mass loss in spring 2004. Nature, 443: 329-331. doi: 10.1038/nature05168.

WAHR J, MOLENAAR M \& BRYAN F. 1998. Time variability of the Earth's gravity field: Hydrological and oceanic effects and their possible 
detection using GRACE. J. Geophys. Res., 103(B12): 30,205-30,229. doi: 10.1029/98JB02844.

WAHR J, SWENSON S, ZLOTNICKI V \& VELICOGNA I. 2004. Timevariable gravity from GRACE: First results. Geophys. Res. Lett., 31, L11501. doi: 10.1029/2004GL019779.

WWF - WORLD WILDLIFE FUND. 2010. Pantanal Program/Climate Change. Available on: <http://bolivia.panda.org/nuestro_trabajo/pro- grama_pantanal >. Access on: June 15, 2012.

XAVIER L, BECKER M, CAZENAVE A, LONGUEVERGNE L, LLOVEL W \& ROTUNNO FILHO OC. 2010. Interannual variability in water storage over 2003-2008 in the Amazon Basin from GRACE space gravimetry, in situ river level and precipitation data. Remote Sensing of Environment, 114(8): 1629-1637. http://doi.org/10.1016/j.rse.2010.02.005

Recebido em 21 novembro, 2016 / Aceito em 7 junho, 2017

Received on November 21, 2016 / Accepted on June 7, 2017 